\title{
Daya Antibakteri dan Waktu Kontak Infusa Teh Hijau (Camellia sinensis) Terhadap Salmonella typhi Secara In Vitro
}

\author{
Dione Margareth Setiawan, Sadeli Masria, Chrysanti \\ Bagian Mikrobiologi \\ Fakultas Kedokteran Universitas Padjadjaran, Bandung
}

\begin{abstract}
Abstrak
The hijau (Camellia sinensis) memiliki beragam efek farmakologik, di antaranya sebagai antibakteri. Salmonella typhi penyebab demam tifoid, masih merupakan masalah kesehatan masyarakat di negara tropis terdapat 20 juta kasus dan 600.000 kematian per tahun di seluruh dunia. Penelitian ini ingin mengetahui daya antibakteri dan lamanya waktu kontak infusa teh hijau dari berbagai merek kemasan terhadap Salmonella typhi secara in vitro dengan menggunakan teknik difusi sumur, selanjutnya data dianalisis dengan ANAVA dan uji t-independen. Penelitian dilakukan di Laboratorium Mikrobiologi Fakultas Kedokteran Universitas Padjadjaran, Bandung pada bulan Maret-April 2009. Hasil menunjukkan infusa dengan konsentrasi 40\% (b/v) kemasan komersial Indonesia memberikan rata-rata diameter daerah hambat 3,376 $\pm 0,334 \mathrm{~mm}$ dan 3,571 \pm 0,217 $\mathrm{mm}$ pada kemasan Jepang $(\mathrm{p}<0,05) ; 0,707 \pm 0,000 \mathrm{~mm}$ pada konsentrasi di bawah $40 \%$ rata-rata daerah hambat. Tidak terdapat perbedaan antara kemasan Indonesia dan Jepang $(\mathrm{p}>0,551)$. Terdapat kekeruhan pada media cair Muller-Hinton dibandingkan dengan media kontrol pada konsentrasi di bawah 40\% Teramatinya pertumbuhan koloni S. typhi pada agar MullerHinton konsentrasi 5\% dan 10\%. Tidak teramati penurunan jumlah koloni S. typhi konsentrasi kurang atau sama dengan $40 \%$ pada pengamatan waktu kontak 0 sampai 60 menit ( $>00,05 ; \alpha=0,05$ ). Kesimpulan menunjukkan teramatinya daya antibakteri infusa teh hijau pada kemasan dengan konsentrasi $40 \%$. Belum teramatinya daya antibakteri infusa dan pengaruh waktu kontak positif pada reduksi pertumbuhan koloni $S$. typhi pada kemasan dengan konsentrasi di bawah 40\%. [MKB. 2010;42(2):51-5].
\end{abstract}

Kata kunci: Teh hijau, infusa, daya antibakteri, waktu kontak, Salmonella typhi

\section{Antibacterial Activities and Time Contact Green Tea Infussion (Camellia Sinensis) Againsts Salmonella Typhi by In Vitro}

\begin{abstract}
Green tea (Camellia sinensis) contains cathecin which has been reported to have various pharmacologic properties, such as an antibacterial agent. Salmonella typhi, as agent of typhoid fever, remains a public health problem in tropical countries; about 20 million cases and 600.000 deaths annually all over the world. Objectives of this research were to observe the antibacterial activities and contact time of green tea infusion againsts Salmonella typhi by in vitro experiment. The experiment took place in Microbiology Laboratory, School of Medicine, Padjadjaran University, Bandung, March-April 2009. Methods: In vitro laboratory analytic study has been conducted on green tea infusion of Indonesian and Japanese commercial package againsts Salmonella typhi. The study used agar well diffusion method and analyzed by ANAVA and t-independent test. Results: Only at concentration of 40\% (w/v), Indonesian green tea infusion gave an average inhibition area of $3.376 \pm 0.334 \mathrm{~mm}$ diameter, and $3.571 \pm 0.217 \mathrm{~mm}$ on Japanese package, while below $40 \%$ were $0.707 \pm 0.000 \mathrm{~mm}$ with no differences between both packages ( $\mathrm{p}>0.551)$. There has been observed any turbidity in all Muller Hinton liquid media on both packages compared with control medium, also any growth of Salmonella typhi collony in all Muller Hinton agar at concentrations below $40 \%$. Green tea infussion on both packages has been observed to have antibacterial activities at $40 \%$ but neither been observed at concentration below 40\%. [MKB. 2010;42(2):51-5].
\end{abstract}

Key words: Green tea, infussion, antibacterial activities, time contact, Salmonella typhi Korespondensi: dr. Dione Margareth, Bagian Mikrobiologi Fakultas Kedokteran Universitas Padjadjaran, Jln. Raya Bandung Sumedang, Jatinangor 


\section{Pendahuluan}

Indonesia, negara penghasil teh terbesar kelima setelah India, China, Srilanka dan Kenya, tetapi konsumsi teh di Indonesia masih tergolong rendah $(0,2 \mathrm{~kg} / \mathrm{kapita} / \mathrm{tahun}){ }^{1}$ Daun teh hijau yang diolah tanpa melalui proses fermentasi mengandung senyawa polifenol sebesar $20-35 \%$ dengan 60 $80 \%$ yang berupa katekin. Katekin utama yang ditemukan pada daun teh hijau di antaranya: (-)-epigalokatekin (EGC), (-)-epikatekin galat (ECG), (-)-epikatekin (EC), (-)-epigalokatekin-3 -galat (EGCG), (+)-katekin (C), (-)-gallokatekin galat (GCG). ${ }^{2}$ Berbagai penelitian melaporkan bahwa katekin dari daun teh hijau memiliki bermacam-macam efek farmakologik, antara lain: antidiabetik, hipokolesterolemia, antiangiogenik, menginduksi apoptosis, antiobesitas, antioksidan, antiinflamasi, antikarsinogenik, antimutagenik, serta mempunyai daya hambat terhadap berbagai mikroorganisme. ${ }^{3-11}$

Salmonella typhi sebagai penyebab demam tifoid, yang masih merupakan masalah kesehatan masyarakat dan penyebab utama morbiditas di negara tropis, tercatat terdapat 20 juta kasus dan 600.000 kematian per tahunnya akibat penyakit tersebut di seluruh dunia. ${ }^{12}$ Pada laporan penelitian Ciraj dkk. ${ }^{13}$ ditemukan adanya aktivitas antibakteri ekstraks alkohol teh hitam terhadap Salmonella typhi pada konsentrasi $2 \%(\mathrm{~V} / \mathrm{V})$.

Penelitian ini dilakukan di Laboratorium Mikrobiologi Fakultas Kedokteran Universitas Padjadjaran, Bandung pada bulan Maret-April 2009. Pada penelitian ini menggunakan metode infusa sebagai metode ekstraksi dengan pelarut air karena pengerjaannya mudah dan murah dibandingkan dengan metode ekstraksi lainnya.

\section{Metode}

Bakteri uji yang diperlukan untuk penelitian ini adalah tujuh isolat $S$. typhi yang berasal dari Laboratorium Sandia, Bandung, serta S. typhi NCTC 786 BFC 712 sebagai bakteri kontrol yang disuspensikan dengan larutan $\mathrm{NaCL}$ 0,9\% sampai kekeruhannya sesuai dengan standar uji McFarland 0,5. Isolat S. typhi diisolasi dari darah dengan menggunakan sistem kultur-darah otomatis komersial BD BACTECTM Plus Aerobic/F* (Becton Dickinson, Temse, Belgium) dan dikultur pada media agar McConkey, lalu diindentifikasi dengan API ${ }^{\circledR}$ 20E (bioMerieux, Inc, France).

Bahan uji yang dipakai adalah dua kemasan teh hijau komersial, yang terdiri dari satu kemasan komersial Indonesia Teh Hijau Tong Tji yang diproduksi oleh Perusahaan Teh Dua Burung Tegal-Indonesia, No. Reg 415046 BPOM RI MD 341211010017, dan satu kemasan komersial Japanese Green Tea yang diproduksi oleh Teh Enam Tiga, Teh dan Kesehatan, DEPKES RI MD 341210001317, yang dibuat dalam bentuk infusa pada konsentrasi uji dari konsentrasi 2,5\%,5\%, $10 \%, 20 \%$, dan $40 \%$ (w/v).

Pada penelitian ini digunakan metode analitik laboratoris untuk menguji daya antibakteri dengan menggunakan teknik difusi sumur (modifikasi Kirby Bauer). Penentuan konsentrasi hambat minimal (KHM) dan konsentrasi bakterisidal minimal (KBM) yang dilakukan dengan teknik pengenceran infusa konsentrasi uji sebanyak 2 kali, serta penentuan waktu kontak teh hijau terhadap S. typhi pada 0, 15,30, 45, dan 60 menit. Data penelitian tersebut dianalisis dengan analisis varians (ANAVA), dan selanjutnya dilakukan uji jarak berganda Duncan. Apabila hasil penelitian menunjukkan tidak ada interaksi maka data hanya membedakan dua perlakuan.

\section{Hasil}

Pada Tabel 1 bahwa hasil penelitian dengan teknik difusi sumur memperlihatkan infusa teh hijau kemasan komersial Indonesia pada konsentrasi $40 \%$ memberikan rata-rata diameter daerah hambat 3,376 $\mathrm{mm}$ dengan standar deviasi 0,334. Kemasan komersial Jepang dengan konsentrasi $40 \%$ didapat rata-rata diameter daerah ham-bat 3,571 mm dengan standar deviasi 0,217. Pada konsentrasi $2,5 \%, 5 \%, 10 \%$, dan $20 \%$ rata-rata diameter daerah hambat di sekeliling sumur infusa teh hijau adalah $0,707 \mathrm{~mm}$ dengan standar deviasi 0,000 .

Hasil uji analisis varians untuk konsentrasi menunjukkan bahwa nilai $\mathrm{p}=0,000$ lebih kecil dari 0,05 sehingga dapat disimpulkan bahwa kelima konsentrasi yaitu 2,50\%, 5\%,10\%,20\%, dan $40 \%$ menunjukkan perbedaan yang sangat bermakna.

Hasil penelitian menunjukkan bahwa rata-rata diameter daerah hambat infusa teh hijau pada konsentrasi $40 \%$ sebesar $1,924 \mathrm{~mm}$ lebih tinggi 
Dione Margareth S.: Daya Antibakteri dan Waktu Kontak Infusa Teh Hijau (Camellia sinensis) Terhadap Salmonella typhi

Tabel 1 Diameter Daerah Hambat Infusa Teh Hijau Kemasan Komersial Indonesia dan Jepang dalam Berbagai Konsentrasi terhadap Salmonella typhi Secara In Vitro dengan Teknik Difusi Sumur

\begin{tabular}{|c|c|c|c|c|c|c|c|c|c|c|}
\hline \multirow[t]{2}{*}{ Isolat } & \multicolumn{5}{|c|}{$\begin{array}{l}\text { Diameter Daerah Hambat Teh Hijau } \\
\text { Komersial Kemasan Indonesia (mm) }\end{array}$} & \multicolumn{5}{|c|}{$\begin{array}{c}\text { Diameter Daerah Hambat Teh Hijau } \\
\text { Komersial Kemasan } \\
\text { Jepang }(\mathrm{mm})\end{array}$} \\
\hline & $2,50 \%$ & $5 \%$ & $10 \%$ & $20 \%$ & $40 \%$ & $2,50 \%$ & $5 \%$ & $10 \%$ & $20 \%$ & $40 \%$ \\
\hline S. typhi 1 & 0,707 & 0,707 & 0,707 & 0,707 & 3,035 & 0,707 & 0,707 & 0,707 & 0,707 & 3,536 \\
\hline S. typhi 2 & 0,707 & 0,707 & 0,707 & 0,707 & 3,391 & 0,707 & 0,707 & 0,707 & 0,707 & 3,279 \\
\hline S. typhi 3 & 0,707 & 0,707 & 0,707 & 0,707 & 0,707 & 0,707 & 0,707 & 0,707 & 0,707 & 0,707 \\
\hline S. typhi 4 & 0,707 & 0,707 & 0,707 & 0,707 & 0,707 & 0,707 & 0,707 & 0,707 & 0,707 & 0,707 \\
\hline S. typhi 5 & 0,707 & 0,707 & 0,707 & 0,707 & 0,707 & 0,707 & 0,707 & 0,707 & 0,707 & 0,707 \\
\hline S. typhi 6 & 0,707 & 0,707 & 0,707 & 0,707 & 0,707 & 0,707 & 0,707 & 0,707 & 0,707 & 0,707 \\
\hline S. typhi 7 & 0,707 & 0,707 & 0,707 & 0,707 & 0,707 & 0,707 & 0,707 & 0,707 & 0,707 & 3,744 \\
\hline $\begin{array}{c}\text { S. typhi NCTC } \\
786 \text { BFC } 712\end{array}$ & 0,707 & 0,707 & 0,707 & 0,707 & 3,703 & 0,707 & 0,707 & 0,707 & 0,707 & 3,727 \\
\hline Rata-rata & 0,707 & 0,707 & 0,707 & 0,707 & 3,376 & 0,707 & 0,707 & 0,707 & 0,707 & 3,571 \\
\hline sd & 0,000 & 0,000 & 0,000 & 0,000 & 0,334 & 0,000 & 0,000 & 0,000 & 0,000 & 0,217 \\
\hline
\end{tabular}

Tabel 2 KHM Infusa Teh Hijau Kemasan Komersial Indonesia dan Jepang dalam Berbagai Konsentrasi Terhadap Salmonella typhi pada Media Cair Muller Hinton Dibandingkan dengan Kekeruhan Media Kontrol Sesuai Standar Mc Farland 0.5

\begin{tabular}{|c|c|c|c|c|c|c|c|c|c|c|c|c|}
\hline \multirow{4}{*}{ Isolat } & \multicolumn{6}{|c|}{ Teh Hijau } & \multicolumn{6}{|c|}{ Teh Hijau } \\
\hline & \multicolumn{6}{|c|}{ Kemasan Indonesia } & \multicolumn{6}{|c|}{ Kemasan Jepang } \\
\hline & $\mathbf{0 , 3 1}$ & 0,62 & 1,25 & 2,5 & 5 & 10 & $\mathbf{0 , 3 1}$ & 0,62 & 1,25 & 2,5 & 5 & 10 \\
\hline & $\%$ & $\%$ & $\%$ & $\%$ & $\%$ & $\%$ & $\%$ & $\%$ & $\%$ & $\%$ & $\%$ & $\%$ \\
\hline S. typhi 1 & keruh & keruh & keruh & keruh & keruh & keruh & keruh & keruh & keruh & keruh & keruh & keruh \\
\hline S. typhi 2 & keruh & keruh & keruh & keruh & keruh & keruh & keruh & keruh & keruh & keruh & keruh & keruh \\
\hline S. typhi 3 & keruh & keruh & keruh & keruh & keruh & keruh & keruh & keruh & keruh & keruh & keruh & keruh \\
\hline S. typhi 4 & keruh & keruh & keruh & keruh & keruh & keruh & keruh & keruh & keruh & keruh & keruh & keruh \\
\hline S. typhi 5 & keruh & keruh & keruh & keruh & keruh & keruh & keruh & keruh & keruh & keruh & keruh & keruh \\
\hline S. typhi 6 & keruh & keruh & keruh & keruh & keruh & keruh & keruh & keruh & keruh & keruh & keruh & keruh \\
\hline $\begin{array}{l}\text { S. typhi } 7 \\
\text { S. typhi }\end{array}$ & keruh & keruh & keruh & keruh & keruh & keruh & keruh & keruh & keruh & keruh & keruh & keruh \\
\hline $\begin{array}{c}\text { NCTC } \\
786 \text { BFC } \\
712\end{array}$ & keruh & keruh & keruh & keruh & keruh & keruh & keruh & keruh & keruh & keruh & keruh & keruh \\
\hline
\end{tabular}

dibandingkan dengan diameter daerah hambat infusa teh hijau pada konsentrasi 2,50\%, 5\%, $10 \%$, dan $20 \%$. Diameter daerah hambat infusa teh hijau antara kemasan komersial Indonesia dan Jepang terhadap $S$. typhi secara in vitro dengan teknik difusi sumur dengan nilai $p$ sebesar 0,551 sehingga dapat disimpulkan bahwa antara kemasan komersial Indonesia dan Jepang tidak menunjukkan perbedaan yang bermakna.

Nilai statistik uji t-independen sebesar 0,588 dengan $\mathrm{p} 0,566$ lebih besar dari $\alpha=0,05$, yaitu tidak terdapat daya antibakteri infusa teh hijau terhadap S. typhi secara in vitro, baik pada teh hijau kemasan komersial Indonesia maupun
Jepang. Pemberian konsentrasi 2,5\%, 5\%, 10\%, $20 \%$, dan $40 \%$ tidak memberikan efek terhadap pertumbuhan S. typhi secara in vitro dengan teknik difusi sumur.

Hasil pengamatan pada media agar dan cair Muller Hinton, dapat disimpulkan bahwa infusa teh hijau tidak memiliki KHM dan KBM terhadap $S$. typhi, yang dapat dilihat masih terdapat kekeruhan pada media cair Muller-Hinton dibanding media kontrol pada konsentrasi $10 \%$, $5 \%, 2,5 \%, 1,25 \%, 0,62 \%$ dan $0,31 \%$ baik pada teh hijau kemasan komersial Indonesia dan Jepang, serta tetap teramatinya pertumbuhan koloni $S$. typhi pada agar Muller Hinton pada konsentrasi 
Dione Margareth S.: Daya Antibakteri dan Waktu Kontak Infusa Teh Hijau (Camellia sinensis) Terhadap Salmonella typhi

Tabel 3 KBM Infusa Teh Hijau Kemasan Komersial Indonesia dan Jepang pada Konsentrasi 10\% dan 5\% Terhadap Salmonella typhi Secara In Vitro pada Media Agar Muller Hinton

\begin{tabular}{|c|c|c|c|c|}
\hline \multirow[t]{2}{*}{ Isolat } & \multicolumn{2}{|c|}{$\begin{array}{c}\text { Pertumbuhan Koloni Bakteri } \\
\text { dengan Teh Hijau Kemasan } \\
\text { Indonesia }\end{array}$} & \multicolumn{2}{|c|}{$\begin{array}{c}\text { Pertumbuhan Koloni Bakteri } \\
\text { dengan Teh Hijau Kemasan Jepang }\end{array}$} \\
\hline & $5 \%$ & $10 \%$ & $5 \%$ & $10 \%$ \\
\hline S. typhi 1 & koloni + & koloni + & koloni + & koloni + \\
\hline S. typhi 2 & koloni + & koloni + & koloni + & koloni + \\
\hline S. typhi 3 & koloni + & koloni + & koloni + & koloni + \\
\hline S. typhi 4 & koloni + & koloni + & koloni + & koloni + \\
\hline S. typhi 5 & koloni + & koloni + & koloni + & koloni + \\
\hline S. typhi 6 & koloni + & koloni + & koloni + & koloni + \\
\hline S. typhi 7 & koloni + & koloni + & koloni + & koloni + \\
\hline S typhi NCTC 786 BFC 712 & koloni + & koloni + & koloni + & koloni + \\
\hline
\end{tabular}

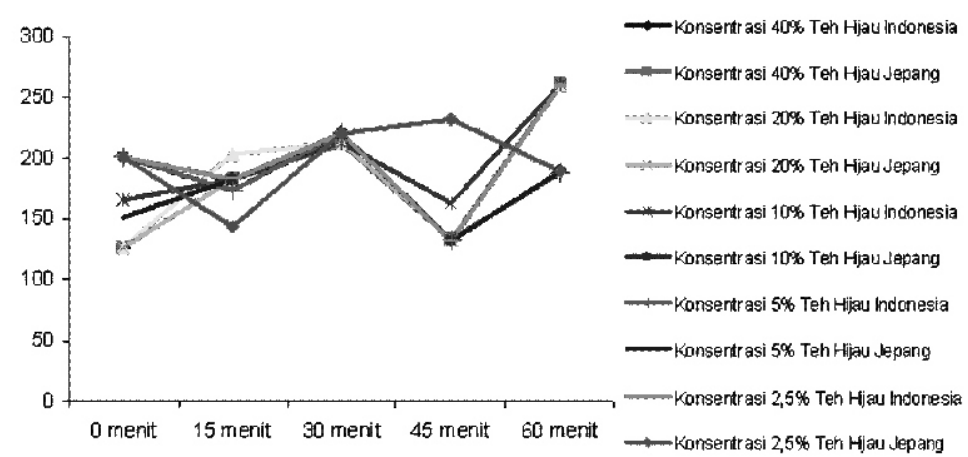

Gambar 1 Pengaruh Waktu Kontak Infusa Teh Hijau Terhadap Pertumbuhan Koloni Isolat Salmonella typhi (dalam 105 CFU) Saat 0, 15, 30, 45, dan 60 Menit Secara In Vitro

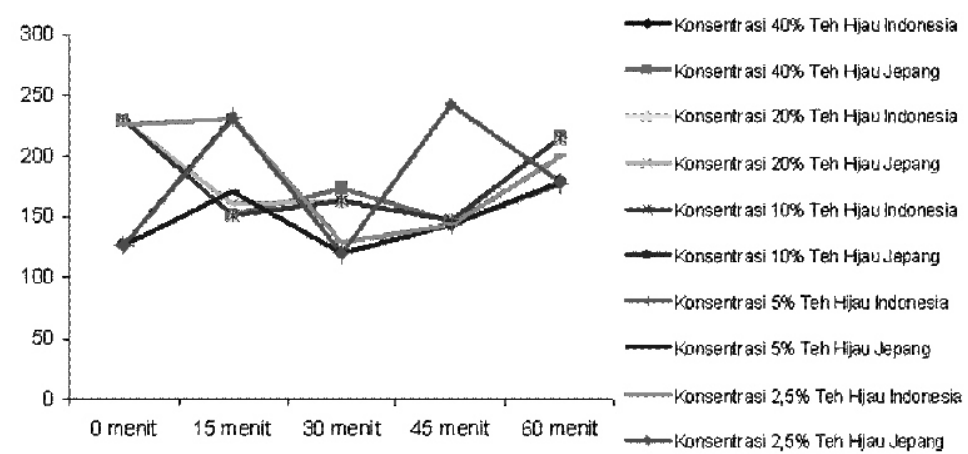

Gambar 2 Pengaruh Waktu Kontak Infusa Teh Hijau Terhadap Pertumbuhan Koloni Salmonella typhi NCTC 786 BFC 712 (dalam 105CFU) Saat 0, 15, 30, 45, dan 60 Menit secara In Vitro

$5 \%$ dan $10 \%$ infusa teh hijau kedua kemasan (Tabel 2 dan 3).

Hasil pengamatan pengaruh waktu kontak 0 , $15,30,45$, dan 60 menit infusa teh hijau dengan konsentrasi $2,5 \%, 5 \%, 10 \%, 20 \%$ dan $40 \%$ pada kemasan komersial Indonesia dan Jepang terhadap $S$. typhi secara deskriptif tidak terdapat penurunan pertumbuhan koloni bakteri (Gambar 1 dan 2).

\section{Pembahasan}

Pada daun teh (Camellia sinensis) mengandung senyawa katekin, di antaranya (-)-epigalokatekin (EGC), (+)-katekin (C), (-)-galoka-tekin galat (GCG), (-)-epikatekin galat (ECG), (-)-epikatekin (EC), serta (-)-epigalokatekin-3-galat (EGCG). ${ }^{2}$ Peneliti terdahulu telah banyak melaporkan 
bahwa katekin sebagai zat aktif yang terkandung di dalam teh hijau yang mempunyai aktivitas penghambatan berbagai mikroorganisme. ${ }^{3-13}$

Pada penelitian ini hanya pada konsentrasi $40 \%$ infusa teh hijau terdapat daerah hambat, sedangkan pada konsentrasi uji lainnya, infusa teh hijau tidak memberikan daerah hambat pada dua kemasan komersial, juga tidak didapatkan KHM dan KBM serta tidak terjadi penurunan jumlah koloni S. typhi pada percobaan waktu kontak 0, 15, 30, 45, dan 60 menit.

Ketidaksesuaian hasil penelitian penulis dengan para peneliti terdahulu diduga karena adanya perbedaan cara penarikan zat aktif, berupa katekin, yang terkandung di dalam daun teh. Seperti diketahui bahwa para peneliti terdahulu menggunakan teknik ekstraksi teh hijau dan produk katekin itu sendiri sebagai bahan uji, yang memiliki kandungan zat aktif lebih tinggi dibandingkan dengan penelitian saat ini yang menggunakan teknik infusa. Kadar zat aktif teh hijau lebih rendah atau tidak ada sama sekali. Perbedaan hasil penelitian tersebut terlihat pada pelaporan Ciraj dkk., ${ }^{13}$ bahwa penggunaan ekstraks alkohol teh hitam mempunyai aktivitas antibakteri terhadap S. typhi dan S. paratyphi. ${ }^{3-13}$

Walaupun pada konsentrasi $40 \%$, infusa teh hijau memberikan daerah hambat di sekeliling sumur, namun secara statistik dinyatakan tidak bermakna ( $p=0,556$ dengan $\alpha=0,05)$ memberikan daya antibakteri terhadap $S$. typhi. Hal tersebut dapat disebabkan adanya proses osmosis pada konsentrasi $40 \%$ yang mengakibatkan lisisnya dinding bakteri.

\section{Daftar Pustaka}

1. Fulder S. Khasiat teh hijau. Jakarta: Prestasi Pustaka Karya; 2004.

2. Ebadi M. Pharmacodynamic basis of herbal medicine. Edisi ke-2. New York: Taylor and Francis Group; 2007.

3. Sakanaka S, Kim M, Tanicuchi M, Yamamoto T.
Antibacterial subtances in japanese green tea extract against Streptococcus mutans, a cariogenic bacterium. Agric Biol Chem. 1989;53(9):230711.

4. Atira. Uji daya antibakteri produk teh (Camellia sinensis L) terhadap Vibrio cholerae dan Shigella dysentriae secara in vitro [tesis]. Bandung: Universitas Padjadjaran, Bandung; 2002.

5. Yamazaki T, Inoue M, Sasaki N, Hagiwara T, Kishimoto $\mathrm{T}$, Shiga $\mathrm{S}$, dkk. In vitro inhibitory effects of tea polyphenols on the proliferation of Chlamydia trachomatis and Chlamydia pneumoniae. Jpn J Infect Dis. 2003 June;56:143-5.

6. Hirasawa M, Takada K. Multiple effects of green tea catechin on the antifungal activity of antimycotics against Candida albicans. JAC. 2004;53 (2):225-9.

7. Minoru H, Kazuo K, Yoshiko S. Antibacterial action on pathogenic bacterial spore by green tea cathecins. J Science of Food Agriculture. 2005 November; 85(14):2354-61.

8. Mbata TI, Debiao LU, Saikia. Antibacterial activity of the crude extract of Chinese green tea (Camellia sinensis) on Listeria monocytogenes. African Biotechnol. 2008 May;7(10):11571-3.

9. Jazani NH, Shahai S, Ali AA, Zartoshti M. Antibacterial effects of water soluble green tea extracts on multi-antibiotic resistant isolates of Acinobacter sp. Pakistan J Biological Sciences. 2007;10(9):1028-80.

10. Jazani NH, Shahabi Sh, Ali AA. Antibacterial effects of water soluble green tea extracts on multi-antibiotic resistant isolates of Pseudomonas aeruginosa. Pakistan J Biological Sciences. 2007; 10(9):1544-6.

11. Taguri T, Tanaka T, Kouno I. Antimicrobial activity of 10 different plant polyphenols against bacteria causing food-borne disease. Bio Pharm Bull. 2004 May;27(12):1965-9.

12. Baliga S. Drug resistance in Salmonella typhi: tip of the iceberg. OJHAS. 2004 OctoberDecember;3(4):1.

13. Ciraj AM, Sulaim J, Marnatha B, Gopalkrishna BK, Shivananda PG. Antibacterial activity of black tea (Camellia sinensis) extract against Salmonella serotypes causing enteric fever. Indian J Med Sciences. 2001;55(7):376-81. 